\title{
[FPSCR
}

\section{Uji Daya Hambat Berbagai Merek Hand Sanitizer Gel terhadap Pertumbuhan Bakteri Escherichia coli dan Staphylococcus aureus}

\author{
Eka P. Rini ${ }^{1}$ dan Estu R. Nugraheni ${ }^{*}$ \\ ${ }^{1}$ Program Studi D3 Farmasi, Fakultas Matematika dan Ilmu Pengetahuan Alam, Universitas Sebelas Maret \\ *email korespondensi : retnaningtyas_n@yahoo.co.id
}

\begin{abstract}
Abstrak: Hand sanitizer merupakan zat antiseptik dengan kandungan zat aktif berupa alkohol dan bahan antimikroba lain yang dapat menghambat pertumbuhan bakteri Gram positif dan Gram negatif pada tangan. Escherichia coli merupakan bakteri Gram negatif sedangkan Staphylococcus aureus merupakan baktei Gram positif dan keduanya secara alami tumbuh pada tubuh dan kulit manusia. Jumlah konsumen hand sanitizer meningkat karena cara pemakaian yang praktis tanpa memerlukan adanya sumber air. Penelitian ini bertujuan untuk mengetahui daya hambat 5 merek hand sanitizer gel terhadap E. coli dan S. aureus serta menganalisis faktor yang menjadi pertimbangan konsumen dalam membeli hand sanitizer dengan merek tertentu. Penelitian dengan 2 metode yaitu uji aktivitas antimikroba melalui terbentuknya zona hambat hand sanitizer terhadap mikroba uji dan analisis waktu penghambatan optimum terhadap pertumbuhan mikroba di telapak tangan. Penentuan sampel dilakukan dengan penyebaran kuisionair dengan teknik accidental sampling. Hasil penelitian menunjukkan bahwa terdapat 3 merek yang mampu menghambat pertumbuhan E.coli dengan aktivitas sedang hingga kuat, dan semua merek hand sanitizer mampu menghambat pertumbuhan S.aureus dengan aktivitas kuat hingga sangat kuat. Dari hasil analisis statistik menunjukkan bahwa data terdistribusi normal dan memenuhi syarat untuk melakukan uji parametrik One Way Annova. Hasil akhir menunjukkan nilai sig $\mathrm{p}<0,005$ terhadap penghambatan S. aureus dan E. Coli, sehingga terdapat perbedaan bermakna antara sampel hand sanitizer terhadap daya hambat pertumbuhan $S$. aureus dan E. coli. Hasil pengujian waktu penghambatan optimum terhadap mikroba di telapak tangan menunjukkan penurunan jumlah koloni bakteri pada rentang waktu 0 hingga 12 menit. Dari hasil pengecatan gram diperoleh hasil bahwa mikroba pada telapak tangan tersebut bersifat gram positif, bentuk kokus, susunan menggerombol dan diperkirakan adalah S.aureus.
\end{abstract}

Kata kunci: Hand sanitizer; daya hambat; Staphylococcus aureus; Escherichia coli

Abstract. The inhibition test of various brand of hand sanitizer gel to the growing of Escherichia coli and Staphylococcus aureus bacteria. Hand sanitizer is an antiseptic substance containing active substances such as alcohol and other antimicrobial agents that can inhibit the growth of Gram-positive and Gram-negative bacterial on hand. Escherichia coli is Gramnegative bacterial while Staphylococcus aureus is Gram-positive bacterial and both naturally growth in the human body and skin. The number consumers of hand sanitizer were increased because practical using without requiring any source of water. This study purposes were determined the inhibition power of 5 brand hand sanitizer gels against $E$. coli and $S$. aureus and analyzed the factors that are considered by consumers to buy a particular brand of hand sanitizer. 
This research is a non-experimental research descriptive research design. Research was conducted by measuring the clear zone of hand sanitizer used disc diffusion methode and was conduct by analysis the optimum inhibition time of hand sanitizer to the growing of E. coli and $S$. aureus during research time. The analysis of consumer consideration factors were done by distributing with sampling technique used accidental sampling. In clear zone test was produced only 3 brands have inhibitory power to the E. coli and all brands of hand sanitizers have inhibitory power to the $S$. aureus. In optimum inhibition to $S$. aureus time that is 1 hand sanitizer brand after 0 to 12 minute, 2 hand sanitizer brands after 6-12 minutes, 1 hand sanitizer brand after 0 to 6 minutes, and 1 hand sanitizer brand after 0 to 3 minutes. Advertising is the most influential factor for consumers to buy a particular hand sanitizer brand

Keywords: Hand sanitizer; clear zone; Staphylococcus aureus; Escherichia coli

\section{Pendahuluan}

Cuci tangan merupakan kegiatan sederhana yang bertujuan untuk menghilangkan kotoran dan meminimalisir jumlah kuman yang ada ditangan dan telapak tangan. Cuci tangan dapat menggunakan air dan suatu zat tambahan, dimana zat tersebut dapat berupa antiseptik atau yang lainnya (Soedarmo, 2012). Mencuci tangan menggunakan air mengharuskan manusia dekat dengan sumber air dan jika tanpa sabun cuci tangan yang mengandung antiseptik maka tidak akan efektif dalam menghilangkan kotoran pada tangan dan tidak menghindarkan manusia dari mikroorganisme berbahaya pada tangan. Seiring berjalannya waktu, mencuci tangan bukanlah satu-satunya cara untuk membersihkan tangan dari kotoran dan mikroba. Terdapat cara yang lebih praktis yaitu dengan menggunakan suatu cairan gel antiseptik yang bisa digunakan dimana saja dan kapan saja tanpa harus membilasnya dengan air, cairan atau gel antiseptik ini disebut "hand sanitizer" (Rachmawati, 2008).

Hand sanitizer merupakan zat antiseptik yang didalamnya terdapat alkohol dengan persentase 60-95\%. Menurut Food and Drug Administration (FDA), Hand sanitizer dapat menghilangkan kuman kurang dari 30 detik. Alkohol yang terkandung pada hand sanitizer memiliki kemampuan aktivitas bakteriosida yang baik terhadap bakteri Gram positif dan Gram negatif. Selain itu, hand sanitizer juga mengandung bahan antibakterial seperti triklosan atau agen antimikroba lain yang dapat menghambat pertumbuhan bakteri pada tangan seperti Escherichia coli dan Staphylococcus aureus (Radji, 2007).

Bakteri Escherichia coli secara normal berada di saluran pencernaan bagian bawah dan akan dapat berubah menjadi patogen jika perkembangan kuman di dalam tubuh melebihi batas normal. Dampak yang muncul pada penderita ialah: menurunnya berat badan dan kondisi tubuh, pertumbuhan terhambat, dan jika tidak segera ditangani dapat menimbulkan kematian . Escherichia coli dapat menyebar melalui debu yang terkontaminasi atau melalui makanan dan minuman yang terkontaminasi ataupun tangan yang terkontaminasi feses (Ginns, 2000).

Staphylococcus aureus adalah bakteri Gram positif mikrokokus yang sering ditemukan pada telapak tangan. Genus stafilokokus sedikitnya memiliki 30 spesies. Tiga spesies utama yang memiliki kepentingan klinis adalah Staphylococcus aureus, Staphylococcus epidermidis, dan staphylococcus saprophyticus. Staphylococcus aureus bersifat koagulase-positif, yang membedakannya dari spesies lainnya. S.aureus adalah patogen utama pada manusia (Jawetz, 2008).

Cara pemakaian yang praktis tanpa memerlukan adanya sumber air dan mematikan kuman secara cepat menjadikan kelebihan utama dari hand sanitizer yang membuat konsumen produk 
ini tertarik untuk membeli produk hand sanitizer. Pada masa sekarang ini, banyak merek hand sanitizer yang berada dipasaran sehingga masyarakat memiliki banyak pilihan untuk membeli produk hand sanitizer dengan merek tertentu.

\section{Bahan dan Metode}

Penelitian jenis non eksperimental dengan desain penelitian deskriptif. Penelitian dilakukan di Universitas Sebelas Maret Surakarta pada bulan Febuari sampai dengan Mei 2017. Terdapat 5 merek hand sanitizer yang digunakan sebagai subjek penelitian yang diperoleh dari salah satu swalayan di Surakarta.

Daya hambat hand sanitizer dilihat dari zona hambat yang terbentuk pada biakan bakteri Escherichia Coli dan Staphylococcus Aureus serta waktu penghambatan optimum dari hand sanitizer yang dilihat dari bakteri Escherichia Coli dan Staphylococcus Aureus yang tumbuh pada jari tangan probandus.Pengujian zona hambat dilakukan dengan mengukur Diameter Daya Hambat (DDH) dari 5 merek hand sanitizer menggunakan metode disc diffusion yaitu dengan merendam disk blank pada sampel kemudian disk blank diletakkan pada media MHA (Mueller Hinton Agar) yang sudah terdapat biakan bakteri uji dan diinkubasi selama 24 jam. Dilakukan replikasi 3 kali dan di analisis dengan one way anova SPSS 19.

Waktu penghambatan optimum dari hand sanitizer diuji dengan penggunaan secara langsung kelima merek hand sanitizer pada probandus dan menempelkan jari pada media agar darah. Pengujian dilakukan selama 12 menit setelah pemakaian dengan jeda penempelan pada media agar setiap 3 menit agar lebih mudah mengetahui penurunan atau peningkatan koloni bakteri yang tumbuh pada media agar setiap 3 menitnya setelah diinkubasi selama 24 jam. Faktor yang menjadi pertimbangan konsumen dalam membeli hand sanitizer merek tertentu dilakukan dengan pembagian quisioner pada 77 responden menggunakan metode pengambilan sampel yaitu accidental sampling dan dianalisis hasil quisioner dengan dipresentasekan setiap bahasannya.

Data yang diperoleh dianalisis dengan one way anova dan dilanjutkan dengan uji Post-Hoc Test. Nilai signifikansi <0,05 menunjukkan perbedaan yang bermakna antar kelompok.

\section{Hasil dan Pembahasan}

\subsection{Zona hambat}

Hand sanitizer gel merek A, B, C, D dan E diuji aktivitas daya hambat terhadap pertumbuhan bakteri Staphylococcus aureus ATCC 25923 dan Escherichia coli ATCC 25922. Daya Hambat ditunjukkan dengan adanya zona hambat pertumbuhan bakteri di sekitar sampel yang diujikan dan diukur kemampuannya dengan diameter daya hambat (DDH).

Diameter Daya Hambat menunjukkan sifat dari disinfektan dan antibakteri dengan beberapa tingkatan yaitu: diameter $>20 \mathrm{~mm}$ menunjukkan daya hambat sangat kuat, diameter 10-20 mm menunjukkan daya hambat kuat diameter 5-10 mm menunjukkan daya hambat cukup (medium) serta diameter $<5 \mathrm{~mm}$ menujukkan daya hambat lemah (David \& Stout, 1971). Hal tersebut berarti hand sanitizer yang tidak menghasilkan zona hambat atau DDH yang dihasilkan 0 maka hand sanitizer tersebut tidak memiliki sifat daya hambat terhadap bakteri uji. Daya hambat tersebut dapat dipengaruhi oleh beberapa hal yaitu :

3.1.1. Zona hambat berdasarkan perbedaan jenis bakteri 
Perbedaan utama dari bakteri Escherichia coli dan Staphylococcus aureus ini terletak pada perbedaan susunan dinding selnya dimana bakteri gram positif didominasi oleh peptidoglikan yang tebal yaitu hingga $90 \%$, sedangkan dinding sel bakteri gram negatif hanya mengandung peplidoglikan 15 hingga 20\%. Senyawa peptidoglikan tersebut bersifat polar sehingga mudah larut pada etanol. Sampel mengandung zat aktif alkohol dengan kadar $60-70 \%$ yang bersifat sama dengan etanol sehingga Aktivitas penghambatan senyawa tersebut dapat dilihat pada besarnya DDH dari mikroba uji yang bersifat gram positif (Staphylococcus aureus). Penghambatan ini efektif pada bakteri tersebut karena lapisan peplidoglikan yang tebal terebut mudah larut pada alkohol.

\subsubsection{Zona hambat berdasarkan viskositas sampel}

Sediaan hand sanitizer yang berupa gel sulit menyerap di media uji sehingga pada beberapa sampel tidak terbentuk zona hambat. Hal ini dapat dilihat pada hasil uji sampel merk B dan $\mathrm{E}$ yang mempunyai bentuk sediaan lebih encer dibandingkan sediaan merk A, C dan D. Tabel 1 juga menunjukkan bahwa sampel A,C, dan D menghasilkan zona hambat hanya pada salah satu bakteri uji bahkan merk A tidak menghasilkan clear zone sama sekali karena bentuk sediaan sampel A, C dan D lebih kental. Kondisi ini mendasari langkah berikutnya untuk melakukan pengenceran pada sampel agar mempermudah disk blank dalam menyerap sampel karena viskositas berpengaruh terhadap difusi sampel dalam media uji, sehingga akan mempengaruhi zona hambat yang terbentuk.

Tabel 1. Data Diameter Daya Hambat 5 merek hand sanitizer

\begin{tabular}{cccc}
\hline \multirow{2}{*}{ Bakteri } & \multirow{2}{*}{ Merek } & \multicolumn{2}{c}{ Rata-rata Diameter Daya Hambat $(\mathbf{m m})$} \\
\cline { 2 - 4 } & & Tanpa pengenceran \pm SE & Pengenceran \pm SE \\
\hline \multirow{3}{*}{ Escherichia coli } & $\mathrm{A}$ & $0 \pm 0$ & $0 \pm 0$ \\
& $\mathrm{~B}$ & $12 \pm 1,53$ & $15 \pm 1,73$ \\
\cline { 2 - 4 } & $\mathrm{C}$ & $5 \pm 0,58$ & $2 \pm 0,58$ \\
\cline { 2 - 4 } & $\mathrm{D}$ & $0 \pm 0$ & $0 \pm 0$ \\
& $\mathrm{E}$ & $19 \pm 1,53$ & $17 \pm 1,53$ \\
\hline \multirow{3}{*}{ Staphylococcus aureus } & $\mathrm{A}$ & $0 \pm 0$ & $7 \pm 1,00$ \\
\cline { 2 - 4 } & $\mathrm{B}$ & $26 \pm 2,31$ & $26 \pm 0,58$ \\
& $\mathrm{C}$ & $0 \pm 0$ & $16 \pm 1,73$ \\
\cline { 2 - 4 } & $\mathrm{D}$ & $11 \pm 1,53$ & $6 \pm 1,16$ \\
\hline & $\mathrm{E}$ & $50 \pm 1,53$ & $29 \pm 1,73$ \\
\hline
\end{tabular}

\subsubsection{Zona hambat berdasarkan zat aktif setiap merek}

Hand sanitizer merek A, C dan D memiliki kemampuan daya hambat yang lebih baik terhadap bakteri Staphylococcus aureus daripada terhadap bakteri Escherichia coli. Hal tersebut karena ketiga merek tersebut hanya mengandung alkohol dengan kadar tertentu saja tanpa tambahan zat antibakteri lainnya. Alkohol dengan kadar 60-70 \% bersifat lebih polar sehingga daya hambat lebih baik pada bakteri Gram positif, oleh karena itu menurut tabel 1, DDH yang dihasilkan hand sanitizer A,C dan D lebih besar pada bakteri Staphylococcus aureus.

Hasil DDH pada hand sanitizer tanpa pengenceran dan dengan pengenceran ditunjukkan pada gambar 1 dan gambar 2 secara berurutan. Hasil DDH dari 5 merek hand sanitizer dianalisis menggunakan one-way anova untuk membandingkan perbedaan DDH yang dihasilkan oleh hand sanitizer gel merek A, B, C, D dan E. 
Tabel 2. Zat aktif pada 5 merek hand sanitizer

\begin{tabular}{|c|c|c|}
\hline Merek & Kandungan zat aktif & Kadar \\
\hline $\mathbf{A}$ & Alkohol & $70 \%$ \\
\hline \multirow[b]{2}{*}{ B } & Alkohol & $60 \%$ \\
\hline & Triklosan & - \\
\hline $\mathrm{C}$ & Alkohol & $60 \%$ \\
\hline D & Alkohol & $60 \%$ \\
\hline $\mathbf{E}$ & tidak tercantum & tidak tercantum \\
\hline
\end{tabular}

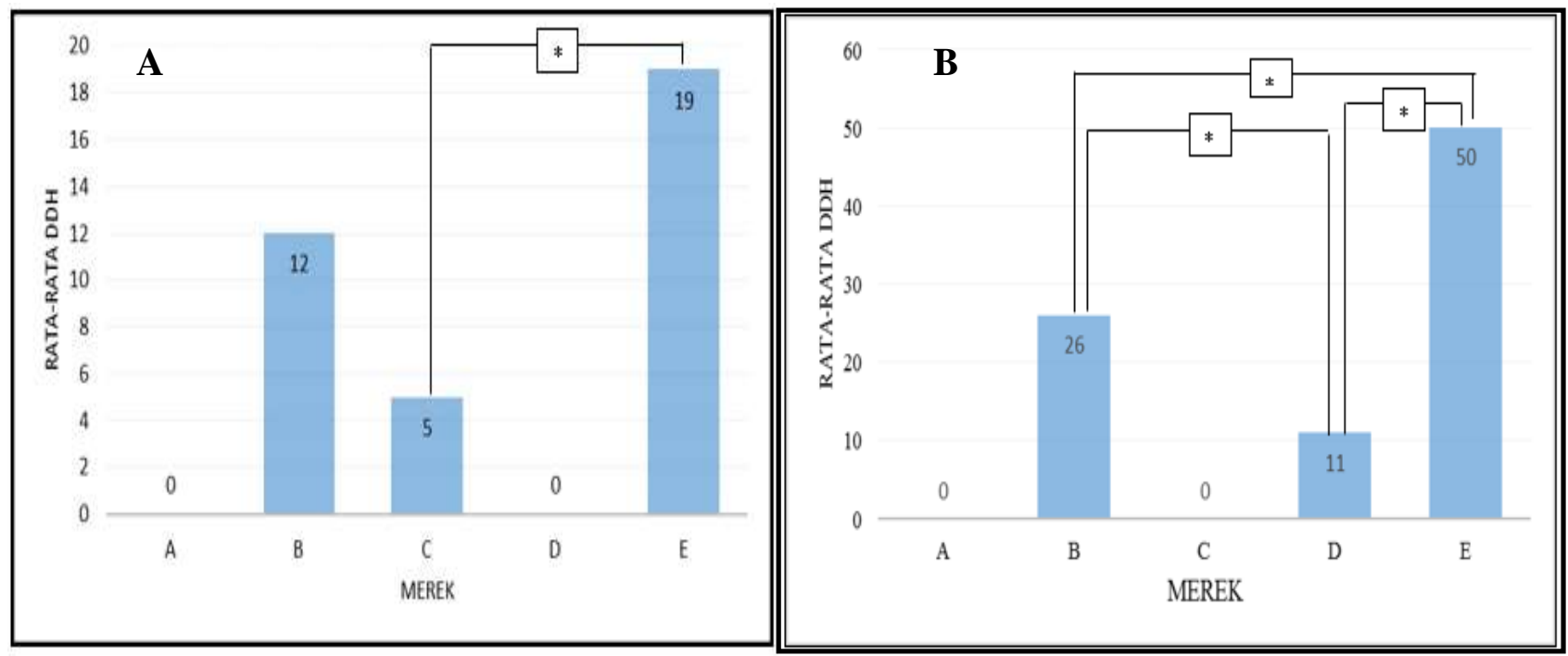

Gambar 1. Diagram rata-rata DDH tanpa pengenceran terhadap E. coli (A) dan S. aureus (B). Tanda bintang $(*)$ menunjukkan perbedaan signifikan rata-rata DDH antar merek.

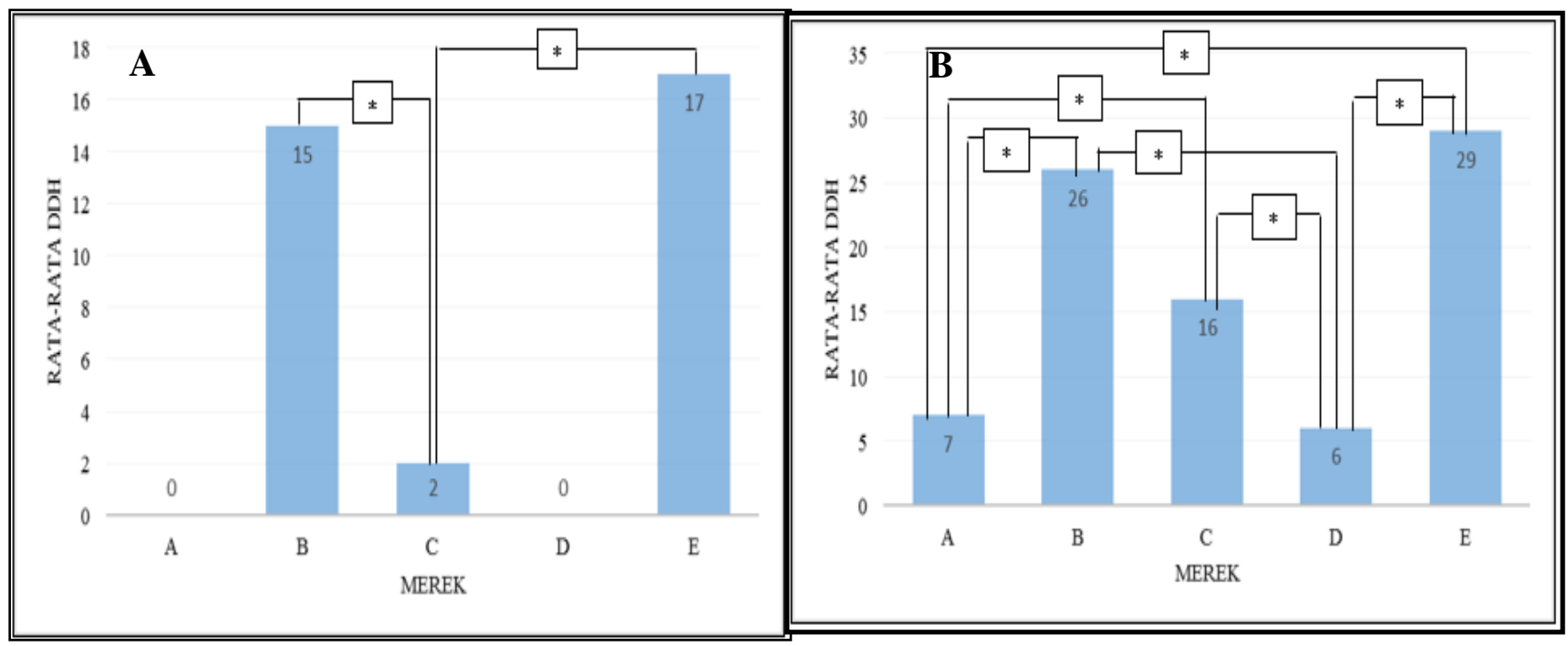

Gambar 2. Diagram rata-rata DDH pengenceran $50 \%$ terhadap E. Coli (A) dan S.aureus (B). Tanda bintang $(*)$ menunjukkan perbedaan signifikan rata-rata DDH antar merek 
Hasil analisis one way anova menunjukkan terdapat merek yang memiliki perbedaan bermakna yang berarti kemampuan daya hambat yang dihasilkan oleh berbagai merek hand sanitizer tersebut juga berbeda (Gambar 1 dan 2). Rata-rata DDH yang paling besar ditunjukkan oleh hand sanitizer merek B dan E. Sedangkan hand sanitizer merek A menurut uji post hoc yang seharusnya juga memiliki perbedaan signifikan dengan merek lainnya karena tidak menghasilkan zona hambat maka rata-rata DDH dari merek A tidak dapat dibandingkan dengan merek lain sehingga pada diagram tidak diberi tanda (*). Hal tersebut berarti hand sanitizer merek A memiliki daya hambat yang tidak baik di bandingkan dengan merek lain karena tidak banyak menghasilkan zona hambat saat pengujian. Begitu juga dengan hand sanitizer merek $\mathrm{C}$ dan $\mathrm{D}$ yang memiliki daya hambat yang baik hanya pada bakteri staphylococcus aureus dibandingkan terhadap Escherichia coli saat tanpa pengenceran maupun saat pengenceran. Perbedaan yang signifikan antar data dilihat dari tanda (*) yang terdapat setelah angka pada setiap data di mean defference. Setelah dilakukan analisis, terdapat beberapa merek yang memiliki perbedaan yang signifikan terhadap merek lainnya.

\subsection{Waktu penghambatan optimum}

Pada penelitian ini, tidak ditemukan bakteri Escherichia coli pada probandus sehingga perhitungan jumlah koloni hanya dilakukan pada bakteri Staphylococcus aureus saja.Waktu penghambatan optimum diartikan sebagai waktu ketika zat aktif dari hand sanitizer bekerja pada waktu terbaik selama pengujian yang terlihat dari koloni bakteri yang terbunuh serta peghambatan terhadap bakteri yang tumbuh kembali. Merek A memiliki penurunan koloni bakteri pada tiap kenaikan waktu pengujian (Gambar 3). Hal tersebut menunjukkan bahwa hand sanitizer merek A waktu penghabatan terhadap pertumbuhan bakteri Staphylococcus aureus yang lebih baik dibandingkan dengan merek lain karena dapat membunuh serta menghambat pertumbuhan bakteri Staphylococcus aureus setelah menit ke 0 hingga menit ke 12, hand sanitizer merek B memiliki waktu penghambatan optimum hanya pada awal pemakaiannya saja dengan membunuh cukup banyak kuman dari menit ke 0 hingga 3, terjadi penurunan jumlah koloni yang cukup baik. Tapi efek tersebut tidak dapat bertahan lama.Hand sanitizer merek C menunjukkan hasil yang jumlah koloni bakteri yang fluktuatif (naik-turun) terhadap pertumbuhan bakteri Staphylococcus aureus pada menit awal pemakaiannya karena koloni bakteri cenderung tetap bahkan justru meningkat pada menit ke yang akan tetapi efek antiseptik dan daya hambat terhadap bakteri Staphylococcus aureus mulai terlihat setelah menit ke 6 menuju menit ke 9 dan 12 karena jumlah koloni bakteri berkurang. Oleh karena itu, dapat diartikan bahwa hand sanitizer merek $\mathrm{C}$ dan $\mathrm{D}$ memiliki waktu penghambatan optimum pada menit ke 6 setelah pemakaiannya hingga menit ke 12 karena dapat menrunkan jumlah koloni bakteri pada menit tersebut.

Hand sanitizer merek E memiliki efek yang hampir sama dengan merek B tetapi hand sanitizer merek E lebih unggul dalam membunuh koloni bakteri Staphylococcus aureus pada menit awal hingga menit ke 6 setelah pemakaiannya. Namun efek tersebut tidak bertahan lama hingga pada menit ke 9, koloni bakteri mengalami peningkatan jumlah sampai menit ke 12 . Hal tersebut berarti waktu penghambatan optimm pada merek E cenderung terjadi setelah menit ke 0 hingga menit ke 6 saja tidak bertahan hingga akhir waktu pengujian. 


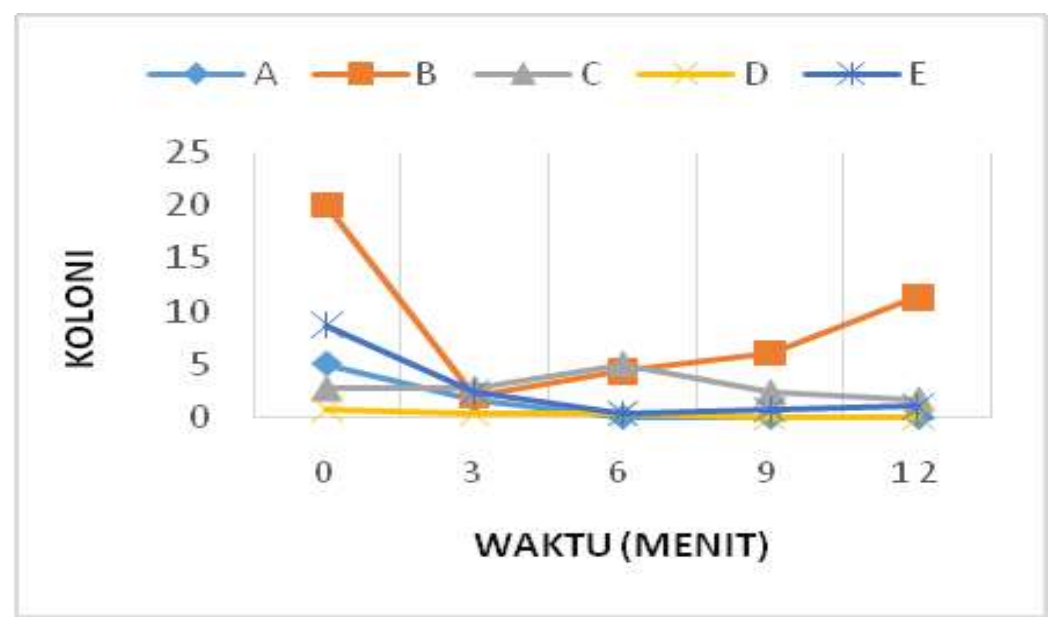

Gambar 3. Grafik waktu penghambatan optimum merek A, B, C, D dan E

\subsection{Kuisioner}

Faktor yang paling banyak pertimbangan konsumen untuk membeli produk hand sanitizer gel dengan merek tertentu dari 4 pilihan yang diberian adalah adanya iklan di media cetak maupun elektronik sebesar 42,80\% (Gambar 4). Pada jaman modern ini, pemasaran produk semakin dipercepat dengan adanya iklan karena kecanggihan teknologi yang dapat menjangkau seluruh masyarakat. Dari tabel 3 terlihat bahwa responden paling banyak membeli hand sanitizer merek $\mathrm{C}$ dengan presetase 45,4 \%. Hand sanitizer gel dengan merek $\mathrm{C}$ paling banyak dibeli karena dalam pemasarannya, hand sanitizer $\mathrm{C}$ telah ada di berbagai iklan di media cetak maupun elektronik dengan ulasan yang unggul tentang produk merek $\mathrm{C}$ sehingga lebih dikenal oleh masyarakat dari berbagai daerah dan berbagai lapisan masyarakat. Selain dari segi iklan, pembelian juga didasarkan pada harga yang ditawarkan oleh produk hand sanitizer tersebut. Dari pembelian tersebut ternyata hand sanitizer merek A memiliki harga yang paling murah yaitu dengan kisaran harga 5.000 rupiah kemudian merek B dengan harga kisaran 7000 rupiah, merek $\mathrm{C}$ dengan kisaran harga 12.000 rupiah, merek D dengan kisaran harga 11.000 dan merek E memiliki kisaran harga 6000 rupiah. Oleh sebab itu, presentase pembeli merek A mencapai 36,4 $\%$ dan menempati posisi hand sanitizer yang paling sering dibeli oleh responden setelah hand sanitizer merek C.

Tabel 3. Persentase pembelian merek hand sanitizer

\begin{tabular}{ccc}
\hline Merek hand sanitizer & Jumlah responden & Persentase Pemnbelian \\
\hline A & 28 & $36,4 \%$ \\
\hline B & 3 & $3,9 \%$ \\
\hline C & 35 & $45,4 \%$ \\
\hline D & 8 & $10,4 \%$ \\
\hline E & 3 & $3,9 \%$ \\
\hline
\end{tabular}

Responden tidak mempertimbangkan komposisi zat aktif (Tabel 2) untuk membeli produk hand sanitizer gel dengan merek tertentu yaitu dengan presentase 14,3\% (Gambar 4). Komposisi bahan pada kemasan produk perlu menjadi bahan pertimbangan karena dalam memilih hand sanitizer karena hal tersebut berhubungan dengan keamanan bahan bagi konsumen. Hand 
sanitizer merek A, C dan D memiliki zat aktif yang baik dan sudah termasuk dalam merek yang aman untuk digunakan sebagai antibakteri menurut CDC dengan kandungan alkohol antara 6095\%. Sedangkan pada merek B yang memiliki kombinasi kandungan alkohol dengan kadar $60 \%$ dan triklosan yang kadarnya tidak dicantumkan. Triklosan memiliki kemampuan antiseptik yang lebih baik daripada alkohol, tetapi triklosan dengan kadar yang tidak sesuai dapat menimbulkan efek negatif bagi penggunanya jika digunakan secara terus-menerus. Begitu juga dengan merek E yang memiliki kemampuan terbaik dalam daya hambatnya terhadap bakteri Escherchia coli dan Staphylococcus aureus menurut pengujian daya hambat dengan zona hambat dan probandus tangan tidak mencantumkan zat aktif pada kemasan. Walaupun memiliki hasil daya hambat yang baik, perlu diperhatikan komposisi dari hand sanitizer yang digunakan karena dapat menimbulkan opini masyarakat tentang aman atau tidaknya produk tersebut ketika digunakan.

Penjelasan diatas sesuai dengan penelitian sebelumya, bahwa mayoritas konsumen memilih hand sanitizer karena pengaruh iklan dari media cetak maupun elektronik kemudian harga dari produk serta hanya beberapa persen yang mempertimbangkan komposisis bahan dan tidak banyak yang mempertimbangkan rekomendasi teman sehingga presentasenya lebih kecil dibandingkan faktor lainnya yaitu yaitu 11,2\% karena biasanya seorang konsumen lebih percaya pada iklan pada televisi yang sering dilihat.

\section{Diagram Konsumen}

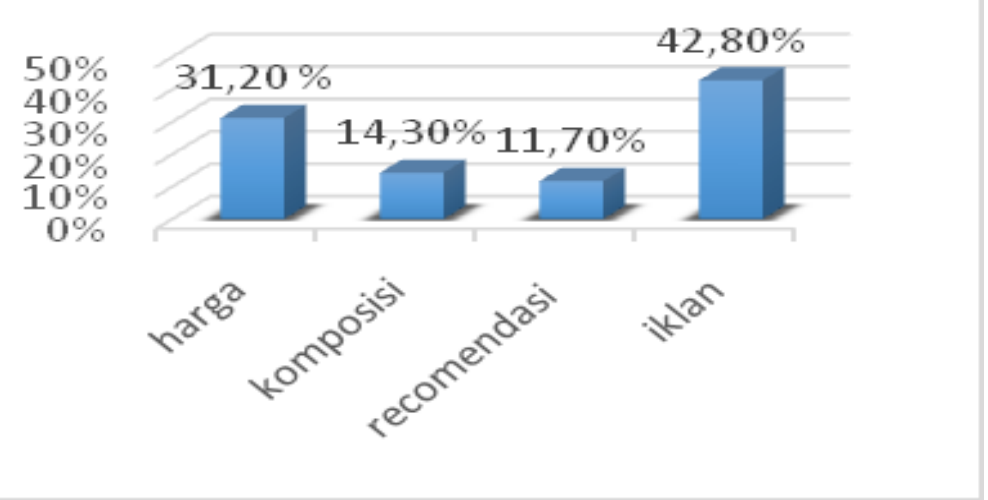

Gambar 4. Diagram presentase alasan pembelian hand sanitizer merek tertentu

\section{Kesimpulan}

Tiga merek hand sanitizer yang memiliki daya hambat terhadap Eschericia coli sedangkan semua merek hand sanitizer memiliki daya hambat terhadap Staphylococcus aureus dengan sifat daya hambat yang lemah hingga sangat kuat. Faktor utama yang menjadi pertimbangan konsumen dalam pembelian produk hand sanitizer adalah iklan di media cetak/ elektronik.

\section{Daftar Pustaka}

Abdat, amali., 2010, Pertumbuhan Streptococcus pneumoniae Pada Agar Darah Manusia Dan Agar Darah Domba, Artikel Ilmiah, Fakultas Kedokteran, Universitas Diponegoro, Semarang.

Anonim, 1982, The Oxoid Manual of Culture Media, Ingredients and other Laboratory Services, 5th ed, Oxoid Limited, UK. 
Anonim, 2015, in vitro-in vivo http://tu.laporanpenelitian.com/2015/07/40.html, diakses tanggal 4 mei

Anonim, 2017, MHA, http://medlab.id/media-mueller-hinton-agar/ diakses tanggal 1 april

Ansari, 1989, Skin Ph And Skin Flora In Handbook Of Cosmetics Science And Technology Third Edition, Informa Healtcare : New York.

Ardi, 2013, Evektivitas Mencuci Tangan Menggunakan Cairan Pembersih Tangan Antisepti (Hand Sanitizer) Terhadap Jumlah Angka Kuman, Jurnal Kesmas, Vol.7 No.2 ,Universitas Ahmad Dahlan : Yogyakarta.

Center for Disease Control, (2005), Introduction to Program Evaluation for Public Health Program : A Self-Study Guide, Atlanta.

David L, Dyer , 2011, Alcohol-Free Instan Hand sanitizer Reduces Elementary Scoool Illness Absenteeism, Kementerian Kesehatan, Jakarta.

Davis, W.W, T,.R. Stout, 1971, Disc plate methods of microbiological antibiotic assay, applied microbiology 22.

Desiyanto, F.A., Siti, N.D., 2013, Efektivitas Mencuci Tangan Menggunakan Cairan Pembersih Tangan Antiseptik (Hand Sanitizer) Terhadap Jumlah Angka Kuman, Jurnal KesMas, Vol,7 No,2, Fakultas Kesehatan Masyarakat, Universitas Ahmad Dahlan, Yogyakarta.

Fardiaz, S, 1993, Analisis Mikrobiologi Pangan, Cetakan Pertama, Raja Grafindo Persada, Jakarta.

Ginns, C.A., 2000, Colonization on the respiratory tract by a virulent strainof Avian E, Coli Requires carriage of conjungatitive plasmid, Infection and immunity, Annual Meeting of the American Educational Research Association, Vol,13 (68), New York.

Husein, U., 2004, Metode Penelitian untuk Skripsi dan Tesis Bisnis, Cetakan ke-6, PT Raja Grafindo Persada, Jakarta.

Jawetz, E, et al, 1996, Mikrobiologi Klinik, Penerbit Buku Kedokteran EGC, Jakarta.

Kustati, F.D., 2013, Pengaruh Sikap Dan Norma Subyektif Terhadap Niat Beli Mahasiswa Sebagai Konsumen Potensial Produk Hand Sanitizer,Tugas Akhir, D3 Farmasi,Fakultas MIPA,UNS, Surakarta.

Pelczar, Michael, J, E,C,S Chan, 1988, Dasar-Dasar Mikrobiologi, UI Press, Jakarta.

Pratiwi, S.T., 2008, Mikrobiologi Farmasi, Penerbit Airlangga, Jakarta.

Rachmawati, F.J., Triyana, S.Y., 2008, Perbandingan Angka Kuman pada Cuci Tangan dengan Beberapa Standarisasi Pembersih Tangan di Lab Mikrobiologi. Logika, Jakarta.

Radji, M., 2007, Uji Efektivitas antimikroba beberapa merk dagang pembersih tangan antiseptik, Majalah ilmu kefarmasian, Vol,IV, No, 1.

Ramadhan, I., 2013, Efek Antiseptik Berbagai Merk Hand Sanitizer Terhadap Bakteri Staphylococcus aureus, Skripsi, Fakultas Kedokteran Dan Ilmu Kesehatan, UIN Syarif Hidayatullah, Jakarta.

Srikartika, P., Netti, S., Eliza, A., 2016, Kemampuan Daya Hambat Bahan Aktif Beberapa Merek Dagang Hand Sanitizer Terhadap Pertumbuhan Stapylococcus aureus, Jurnal Kesehatan, Vol 5 no,3, Andalas.

Strohl, W.A., Rouse, H., Fisher B.D., 2001, Microbiology, Lippincott Williams \& Wilkins, USA. Theodorus, 2010, Antiseptik-disinfektan, Pengajar Departemen Farmakologi Fakutas Kedokteran Universitas Sriwijaya, Kumpulan kuliah farmakologi, EGC, Palembang.

Tortora, 1998, Mycrobiology An Introduction Pearson Education : San Fransisco.

Trampuz, And Widmer, 2004, Hand Hygine Frequently Missed Live Saving Opportunity During Patient Care, Mayo Clinic Proceedings, hal : 109-116.

World Health Organization, 2006, WHO Guidelines on Hand Hygiene in Healthcare (Advanced Draft), World Health Organization.

World Health Organization, 2009, WHO Guidelines On Hand Hygiene In Health Care: Firstglobal Patient Safety Challenge Clean Care Is Safer Care, WHO Press, France. 